\title{
Morphological descriptions of the eggcases of skates (Rajidae) from the central-western Mediterranean, with notes on their distribution
}

\author{
Cristina Porcu ${ }^{1 *}$, Martina F. Marongiu ${ }^{1}$, Andrea Bellodi ${ }^{1}$, Rita Cannas $^{1}$, Alessandro Cau ${ }^{1,2}$, Riccardo Melis ${ }^{1}$, \\ Antonello Mulas' ${ }^{1}$ Giuditta Soldovilla', Laura Vacca ${ }^{1}$ and Maria C. Follesa ${ }^{1}$
}

\begin{abstract}
Eggcases of eight rajiform skates (Dipturus nidarosiensis, D. oxyrinchus, Leucoraja melitensis, Raja asterias, R. brachyura, $R$. clavata, R. miraletus and R. polystigma) present in the central-western Mediterranean are described, based on specimens obtained from fishery surveys. Eggcase features such as dimensions, horns and apron lengths, and presence/ absence of lateral keels were crucial to discriminate the eggcases of the various species. Morphological and morphometric data, confirmed by the multivariate analysis, indicated that the eggcase of $R$. miraletus and $L$. melitensis were distinct from those of the other species for being unkeeled. Within the species having keeled eggcases, those of the genus Dipturus and $R$. brachyura were discriminated from the remaining group by having the largest dimensions and aprons. Sandy bottoms ( $<100-150 \mathrm{~m}$ depth) were identified as egg-laying sites (i.e. sites with females bearing eggcases in uteri) for many species belonging to genus Raja Raja asterias, R. brachyura, R. miraletus and R. polystigma). The finding of $R$. asterias and $R$. miraletus carrying eggcases yearly on the same sites, seems to confirm the theory that many rajid species demonstrate site fidelity, returning to the same depositional area on an annual basis. Some remarks on reproductive biology of these skates are also provided. The eggcase identification key reported here represents the first for the Mediterranean and may be useful, in the future, to identify egg-laying grounds of skates with a nonlethal method.
\end{abstract}

Keywords: Rajidae, Mediterranean Sea, Eggcases, Identification key, Distribution

\section{Background}

The Rajidae family represents the most species-rich group among cartilaginous fish, having 30 genera and 245 valid species [1]. These demersal elasmobranchs often have limited, well-defined distributions, presumed low natural mortality [2] and are an important component of marine biodiversity. Many species live close to shore, generally at depths $<100 \mathrm{~m}$ [3]. Some species are known to undertake seasonal migrations towards egg-laying grounds which maybe located close to shore [4], or over

\footnotetext{
*Correspondence: cporcu@unica.it

1 Department of Life and Environmental Sciences (DISVA), University of Cagliari, Via Fiorelli 1, 09126 Cagliari, Italy

Full list of author information is available at the end of the article
}

continental slopes, and usually discovered during exploratory surveys [5].

Among elasmobranchs, skates, together with the Scyliorhinidae family and the Heterodontiformes order, are the only strictly oviparous group [6] producing a tough eggcase that preserves the embryo development, ranging from months to years depending on the species $[7,8]$. Most rajids show single oviparity (i.e., one embryo per eggcase), with pairs of eggcases (one from each oviduct) deposited during the spawning season [9]. The few exceptions include Raja pulchra [10] and $R$. binoculata [11], which can produce multiple embryos in each eggcase.

One of the greatest issues characterizing this family is historically linked to their taxonomy, often problematical, 
due to phenotypic similarity between some taxa and individual variability in others, and are responsible for their misidentification, related probably to biological and environmental characteristics. Another tool to distinguish skate species from each other, after examining their external morphology, is looking at their eggcases morphology. This feature is unique to these species and can be used for their identification [10, 12-17]. Moreover, the finding of sites where demersal eggcases are laid on the bottom gives information concerning distribution and reproductive ecology $[16,18]$, such as the spawning habitats.

Four genera of Rajidae live in the Mediterranean basin (Dipturus, Leucoraja, Raja and Rostroraja) with 16 possible valid species [19]. In spite of the fact that chondrichthyan reported landings in the Mediterranean Sea have considerably increased in recent years [20], many aspects of their reproductive biology are still unknown. Eggcases have been described for some skates in the Mediterranean basin $[15,22,23]$, but there are few published data on their lengths and widths. Furthermore, regional identification keys based on eggcase morphology and comparative studies are lacking.

The aim of this work is to provide a detailed morphometric and morphological description of eight Mediterranean skate species eggcases, providing also comparisons with previously published data. In particular, seven of these were caught around Sardinian waters, central-western Mediterranean (Dipturus nidarosiensis recently reported for the Mediterranean [24, 25], D. oxyrinchus, Raja asterias, $R$. brachyura, $R$. clavata, $R$. miraletus and $R$. polystigma) and only one (Leucoraja melitensis) was found in the Sentinelle Bank (Sardinian Channel, off the Sardinian waters). Moreover, a specific key that could be useful in the identification of eggcases found on the sea bed, information on the distribution of active females per species and a brief description of the bottom biocenosis, useful to identify possible nursery sites for these vulnerable organisms, were provided.

Furthermore, given the common pattern for which an intraspecific latitudinal cline in elasmobranch sizes between Atlantic and Mediterranean species (e.g. [26]) exists, it could be hypothesized that the same dynamic could be reflected in the eggcase dimensions [27, 28]. For this reason, we investigated in this way, considering also the interspecific variability of eggcases, that may represent an adaptation to several kind of bottoms in order to minimize the competition for nursery grounds.

\section{Methods}

Active females (i.e. with eggcases in the uteri or extruding from the cloaca; henceforth referred to as active) of seven rajids present in Sardinian waters (central-western
Mediterranean Sea), were collected between 2005 and 2016 during seasonal experimental surveys and commercial hauls (trammels and trawlings) at depths from 28 to $1700 \mathrm{~m}$. Additional active individuals belonging to L. melitensis were caught in 2017 (February and March) during commercial trawlings in the "Sentinelle Bank" at $200 \mathrm{~m}$ of depth from a vessel registered in a Sardinian district (Cagliari).

For each individual, the total length (TL) was recorded in millimeters $(\mathrm{mm})$.

For an accurate identification, eggcases were removed directly from the uteri of active females, except those of D. nidarosiensis specimens, which were collected from the sea bed. Eggcases were photographed using a Canon EOS $1100 \mathrm{D}$, preserved in $80 \%$ ethanol and deposited in the collection at the Department of Life and Environmental Sciences, University of Cagliari, Italy. To assure a proper identification of a fully formed embryo found within an eggcase on the sea floor, presumably belonging to $D$. nidarosiensis, a piece of muscle was collected from the embryo and stored in absolute ethanol at $-20{ }^{\circ} \mathrm{C}$ in order to proceed to the genetic identification. The COI-3 primers cocktail and PCR conditions from Ivanova et al. [29] were used to amplify the cytochrome oxidase I gene (COI).

As reported by Gordon et al. [30], the term "anterior" used in this work is considered to refer to the part that forms first in the oviducal gland. Ten morphometric measures (Fig. 1) were recorded in millimeters using a caliper following Concha et al. [31]: eggcase length (ECL, measured longitudinally between the anterior and posterior apron borders); eggcase width (ECW, the transverse width of the eggcase in its lateral plane included the keels); anterior and posterior apron length (AAL and PAL, the distance from the central body eggcase to the apron border); left and right keel width (LKW and RKW, the transverse width of the case from the eggcase keel junction to the keel edge); left and right anterior horn length (LAHL and RAHL, the distance from the anterior apron border to the horn tips); left and right posterior horn length (LPHL and RPHL, the distance from the posterior apron border to the horn tips). All measurements were then expressed in \% of ECL and ECW in order to easily compare them to the others. The measurements in millimeters were also reported to contrast with those present in literature. In addition, the general morphology (shape and other features), fresh color (using the Pantone Matching System, PMS, Carlstadt, NJ, USA), texture and presence and position of adhesion fibres were recorded.

\section{Statistical analysis}

The PRIMER (v6) package [32] was used to analyze the morphometric measures matrix. The outcomes were 


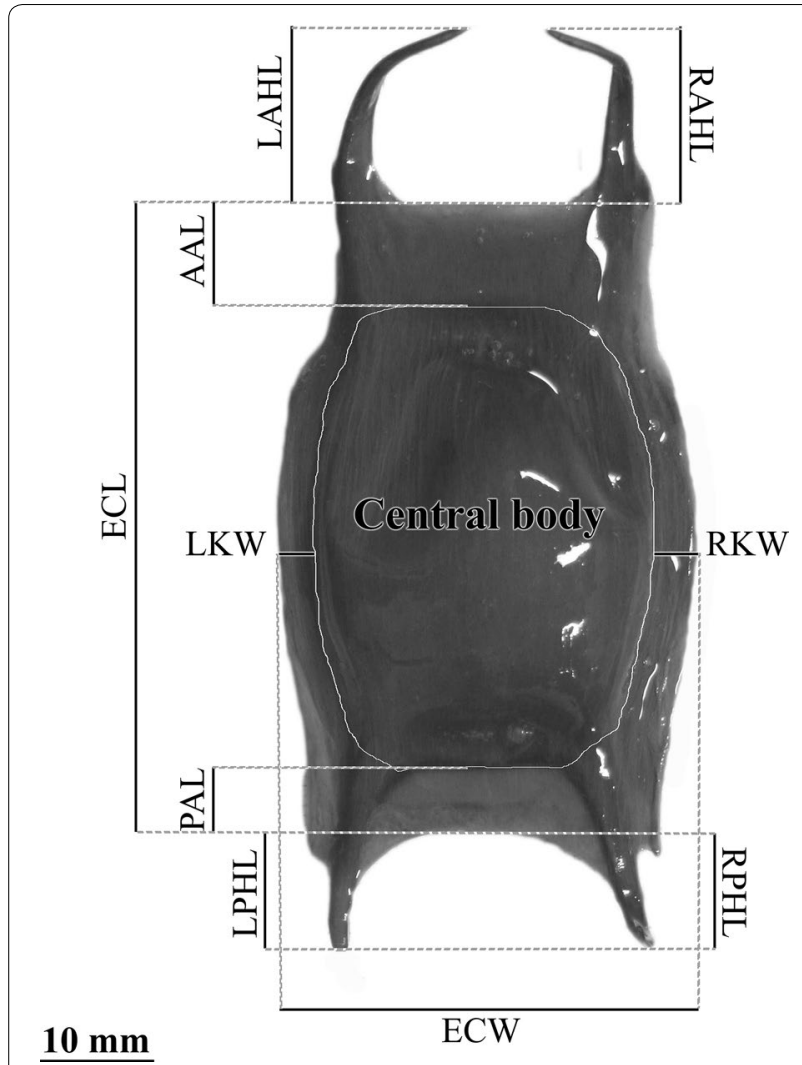

Fig. 1 Morphometric measurements performed in the eggcases. $A A L$ anterior apron length, ECL eggcase length, ECW eggcase width, $L A H L$ left anterior horn length, LKW left keel width, LPHL left posterior horn length, PAL posterior apron length, RAHL right anterior horn length, $R K W$ right keel width, $R P H L$ right posterior horn length

subjected to a Principal Component Analysis (PCA). The components that mostly contributed to the variance were identified. In addition, the SIMPER procedure (SIMilarity PERcentage Analysis) was used to identify those measures responsible for discriminating between groups. The observed differences between groups were tested using an analysis of Similarity Randomization Test (ANOSIM) [33]. Moreover, for each species, the geographical coordinates where females carried eggcases were visualized were provided using Mapsource software version 6.16.3 (Garmin). During fishing activities, the benthic community, associated with the bottom at each site, found in the net, was recorded. For each haul, all taxa were identified following the taxonomic guide for the Mediterranean [34] and in addition number and weight of every species (if possible) were registered in order to determine their abundance.

\section{Results}

A total of 177 eggcases of eight rajid species were examined and measured.

\section{Eggcase description \\ Genus: Dipturus}

Dipturus nidarosiensis (Storm, 1881) $(n=5)$

During the sampling period, only one female carrying eggcases (not yet fully formed with only anterior horns and the apron visible) was caught in September 2015 at a depth of $991 \mathrm{~m}$ (Table 1). However, one eggcase containing a well-developed embryo and four empty eggcases were trawled at depths of 974-1212 m.

The embryo was a male (TL $193 \mathrm{~mm}$ ) showing the typical features of this species: medium brown to greybrownish dorsal surface and dark brown ventral surface, darker than the dorsal surface. The embryo's sequence (658 bp long) was compared to 38 COI sequences of the genus Dipturus from Cariani et al. [35] and resulted identical to the specimens of $D$. nidarosiensis from the Mediterranean Sea (GenBank accession id: KT307210).

The eggcase appeared very large (Fig. 2a) reaching a maximum of $177 \mathrm{~mm}$ ECL (Table 2). The width was $43.9 \%$ of the length, giving a long rectangular shape (Table 3). Anterior and posterior aprons were well developed (25.1

Table 1 Females carrying eggcases analyzed from 2005 to 2017, represented by species, total length (TL) range, depthrange and mean (mean \pm SD) and sampling time

\begin{tabular}{|c|c|c|c|c|c|c|c|c|c|c|c|c|c|c|}
\hline \multirow[t]{2}{*}{ Species } & \multirow[t]{2}{*}{ TL range (mm) } & \multirow[t]{2}{*}{ Depth range $(\mathrm{m})$} & \multicolumn{12}{|c|}{ Sampling time } \\
\hline & & & $J$ & $\mathbf{F}$ & $\mathbf{M}$ & A & $\mathbf{M}$ & $J$ & $J$ & A & $\mathrm{S}$ & $\mathrm{O}$ & $\mathbf{N}$ & D \\
\hline Dipturus nidarosiensis & 1376 & 991 & & & & & & & & & 1 & & & \\
\hline Dipturus oxyrinchus & 1010-1070 & $100-620(500 \pm 144)$ & 5 & 2 & 4 & & 4 & 4 & 1 & 1 & & 4 & 3 & 3 \\
\hline Leucoraja melitensis & $335-382$ & 200 & & 1 & 3 & & & & & & & & & \\
\hline Raja asterias & $517-725$ & $28-92(44 \pm 13)$ & & & & & 1 & 37 & 34 & 7 & & & & \\
\hline Rajabrachyura & $730-1060$ & $30-62(47 \pm 9)$ & & & & & 3 & 7 & 6 & 3 & & & & \\
\hline Raja clavata & $610-871$ & $42-473(144 \pm 118)$ & 3 & 1 & & & & 8 & 4 & 3 & & & & \\
\hline Raja miraletus & $346-481$ & $32-158(69 \pm 24)$ & 3 & & & & 2 & 39 & 13 & 17 & & & & \\
\hline Raja polystigma & $512-595$ & $38-126(56 \pm 24)$ & & & & & & 7 & 4 & 1 & & & & \\
\hline
\end{tabular}

In italics, the number of females carrying eggcases per month 
and $20.2 \%$ of ECL, respectively): the first was straight, on the contrary, the latter was rounded and slightly shorter (Table 3). Both anterior and posterior horns were short (presumably damaged) and lateral keels were present and well developed (9.0\% of ECW) (Table 3$)$. It possessed adhesion fibrils attached to the keels, and in the dorsal and ventral surfaces.

\section{Dipturus oxyrinchus (Linnaeus, 1758) $(n=37)$}

Active females were found during all months of the year, except in April and September, at a mean depth of $500 \mathrm{~m}$ (Table 1).

This species (Fig. 2b) had a smaller eggcase than its congeneric $D$. nidarosiensis with a maximum of $116.2 \mathrm{~mm}$ ECL (Table 2). The eggcases had a rectangular shape (Table 3), since the ECW was $54.9 \%$ of ECL. Anterior and posterior aprons were well developed (25.1 and $14.2 \%$ of ECL, respectively), and the anterior one was longer and straighter in contrast to the posterior, which was more rounded and shorter (Table 3). Horns were short with anteriors slightly longer and tapered then the posterior ones (33.7 and 31.3\% of ECL, respectively). Lateral keels were pronounced $(9.6 \%$ of ECW) and had adhesive fibres.
The fresh color varied from brown shades (PMS 4485, 1535) to greenish ones (PMS 3975) (Fig. 2b; Table 3).

\section{Genus: Leucoraja}

Leucoraja melitensis (Clarke, 1926) $(n=6)$

Females with eggcases were caught in the Sentinelle Bank

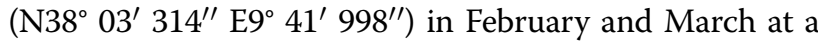
depth of $200 \mathrm{~m}$ (Table 1). L. melitensis had small eggcases (45.0 mm ECL maximum, Table 2), rectangular in shape (ECW $54.0 \%$ of ECL). Anterior apron (13.5\% of ECL) was longer then the posterior one (1.7\% of ECL). The posterior horns were moderate and thin, differently from the anteriors, very long, thin and intersecting (103.9\% of ECL). No lateral keels were observed and the surface was smooth and semi-transparent with no external fibres covering the surface (Fig. 2c). The fresh color was yellowish (PMS 110) with brown shades (PMS 125) (Table 3).

\section{Genus: Raja}

Raja asterias Delaroche, $1809(n=59)$

Active females were found in late spring and summer (May to August) exclusively on the continental shelf (28-92 m depth) (Table 1). The eggcases (Fig. 2d) were

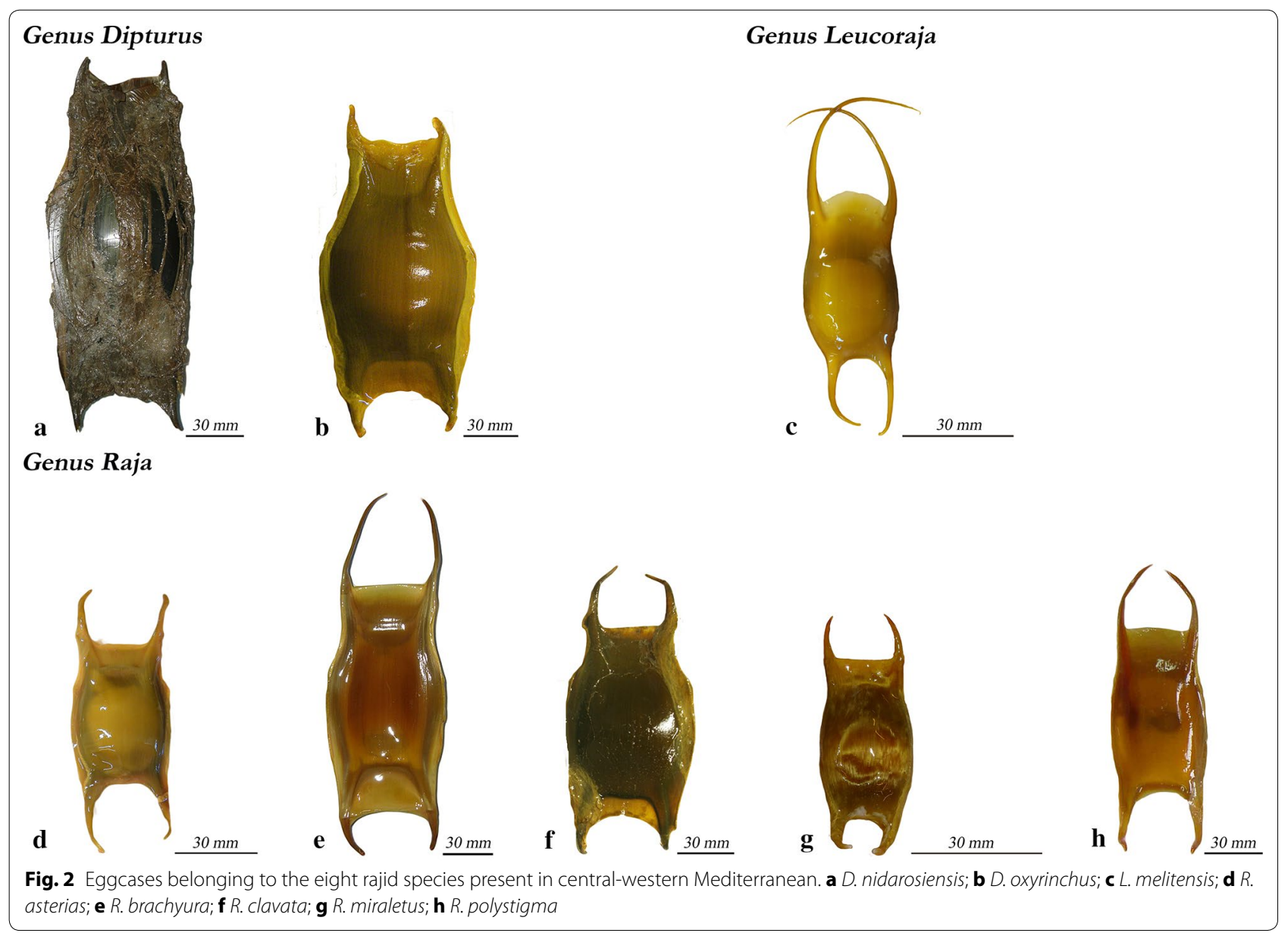




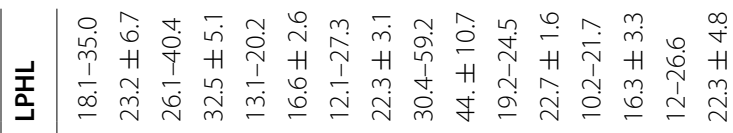

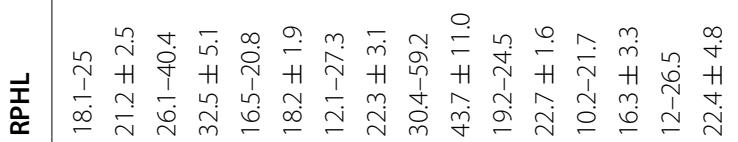

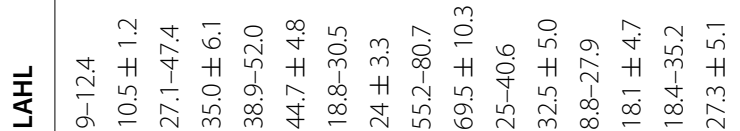

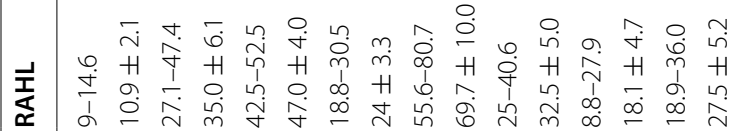

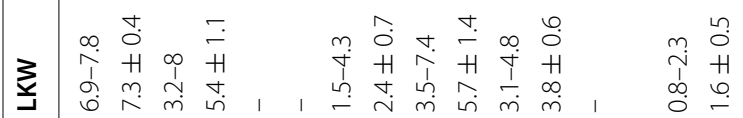

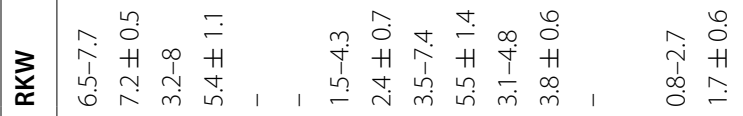

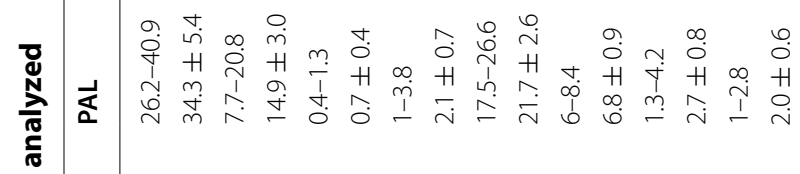

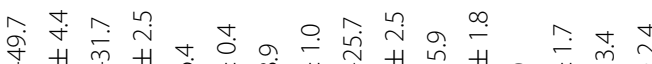

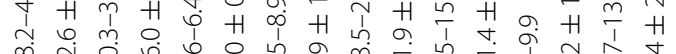

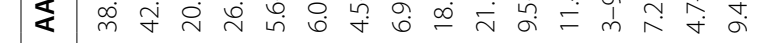

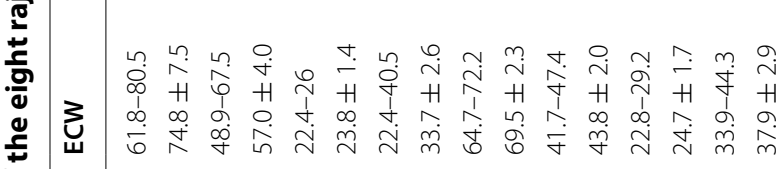

○

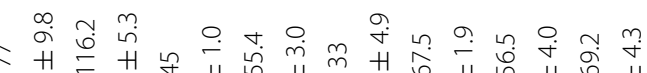

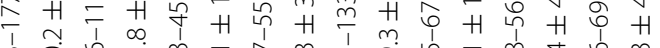

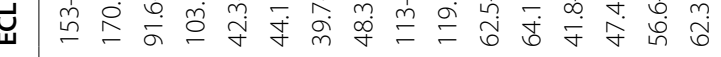

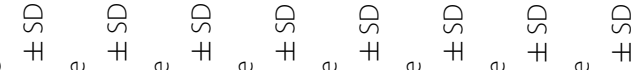

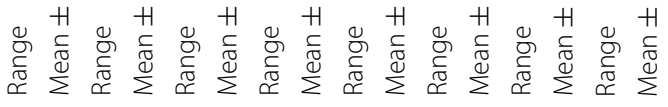

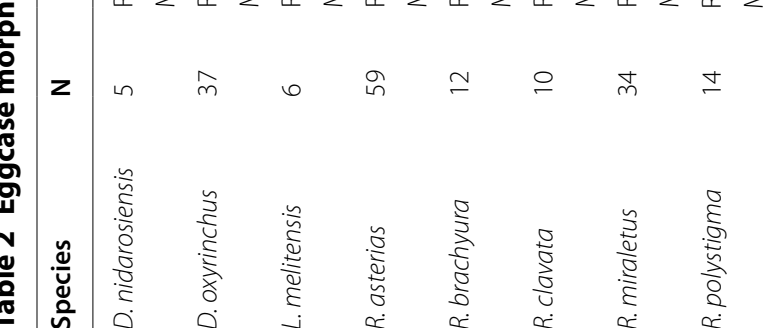


Table 3 General description of rajid eggcases

\begin{tabular}{|c|c|c|c|c|c|c|c|}
\hline Species & Shape & $\begin{array}{l}\text { Anterior } \\
\text { horns }\end{array}$ & Posterior horns & Anterior apron & Posterior apron & Keels & Fresh color \\
\hline D. nidarosiensis & Long rectangular & Short & Short and sturdy & $\begin{array}{l}\text { Straight and well } \\
\text { developed }\end{array}$ & $\begin{array}{l}\text { Rounded and well } \\
\text { developed }\end{array}$ & Well evident & - \\
\hline D. oxyrinchus & Rectangular & Short & Short and sturdy & $\begin{array}{l}\text { Straight and well } \\
\text { developed }\end{array}$ & $\begin{array}{l}\text { Rounded and well } \\
\text { developed }\end{array}$ & Well evident & $\begin{array}{l}\text { Shades of brown (PMS } \\
4485,1535), \text { and } \\
\text { greenish (PMS 3975) }\end{array}$ \\
\hline L. melitensis & Rectangular & $\begin{array}{l}\text { Long, thin and } \\
\text { intersecting }\end{array}$ & Moderate and thin & $\begin{array}{l}\text { Rounded and } \\
\text { moderate }\end{array}$ & $\begin{array}{l}\text { Rounded and } \\
\text { narrow }\end{array}$ & Absent & $\begin{array}{l}\text { Yellowish (PMS 110) } \\
\text { with brown shades } \\
\text { (PMS 125) }\end{array}$ \\
\hline R. asterias & Rectangular & $\begin{array}{l}\text { Moderate and } \\
\text { thin }\end{array}$ & Moderate and thin & Straight & $\begin{array}{l}\text { Rounded and } \\
\text { narrow }\end{array}$ & Evident & $\begin{array}{l}\text { Yellowish (PMS 110) } \\
\text { with brown shades } \\
\text { (PMS 125) }\end{array}$ \\
\hline R. brachyura & Rectangular & Long and thin & Short and sturdy & $\begin{array}{l}\text { Straight and well } \\
\text { developed }\end{array}$ & $\begin{array}{l}\text { Rounded and well } \\
\text { developed }\end{array}$ & Well evident & $\begin{array}{l}\text { Reddish brown (PMS } \\
469 \text { ) and greenish } \\
\text { (PMS 399) }\end{array}$ \\
\hline R. clavata & $\begin{array}{l}\text { Rectangular almost } \\
\text { square }\end{array}$ & $\begin{array}{l}\text { Moderate and } \\
\text { thin }\end{array}$ & Short and sturdy & $\begin{array}{l}\text { Straight and mod- } \\
\text { erate }\end{array}$ & $\begin{array}{l}\text { Rounded and } \\
\text { moderate }\end{array}$ & Well evident & $\begin{array}{c}\text { Reddish brown (PMS } \\
\text { 1395, 139), yellow- } \\
\text { ish brown (PMS 119) }\end{array}$ \\
\hline R. miraletus & Rectangular & Short and thin & Short and sturdy & Straight & $\begin{array}{l}\text { Rounded and } \\
\text { narrow }\end{array}$ & Absent & $\begin{array}{l}\text { Brown (PMS 161) and } \\
\text { amber (PMS 138) }\end{array}$ \\
\hline R.polystigma & Rectangular & $\begin{array}{l}\text { Moderate and } \\
\text { thin }\end{array}$ & $\begin{array}{l}\text { Moderate and } \\
\text { sturdy }\end{array}$ & $\begin{array}{l}\text { Straight and mod- } \\
\text { erate }\end{array}$ & $\begin{array}{l}\text { Rounded and } \\
\text { narrow }\end{array}$ & Narrow & $\begin{array}{l}\text { Brown (PMS 133, 161) } \\
\text { and yellowish (PMS } \\
\text { 126) }\end{array}$ \\
\hline
\end{tabular}

small (55.4 mm ECL maximum, Table 2) with a rectangular shape (ECW $70.0 \%$ of ECL). Aprons were different to each other: the posterior was rounded and narrow $(4.3 \%$ of ECL), and the anterior was straight and long (14.2\% of ECL) (Table 3). Anterior and posterior horns were moderate in length and thin (49.6 and $46.0 \%$ of ECL, respectively). Lateral keels were pronounced (2.4\% of ECW) with adhesive fibres (Table 3). The fresh color was yellowish (PMS 110) with brown shades (PMS 125) (Fig. 2d; Table 3).

\section{Raja brachyura LaFont, $1873(n=12)$}

Active females were caught from May to August in shallow waters (30-62 $\mathrm{m}$ depth) (Table 1). The eggcases had a rectangular shape (ECW about $58.3 \%$ of ECL) and were large in size (maximum ECL $=133 \mathrm{~mm}$ ) (Fig. 2e; Tables 2, 3). Posterior apron was rounded and pronounced and the anterior one was slightly longer and straighter (Table 3). The posterior horns were short and sturdy, while the anterior ones were thin and long (18.2\% of ECL). Keels were developed (8.3\% of ECW) and had attachment fibres. The fresh color was reddish brown in the eggcase body (PMS 469) and greenish (PMS 399) in the edges along the keels (Fig. 2e; Table 3).

\section{Raja clavata (Linnaeus, 1758$)(n=10)$}

Active females were sampled during the summer (from June to August) and winter months (January and February) displaying a broad bathymetric distribution (42$473 \mathrm{~m}$ depth) (Table 1).
This skate had a medium size eggcase (maximum $\mathrm{ECL}=67.5 \mathrm{~mm}$, Table 2) with a rectangular shape (ECW $68.3 \%$ of ECL) (Fig. 2f). The eggcases had a rounded anterior apron and a straight posterior one (Table 3); the former was longer than the posterior one (17.8 and $10.6 \%$ of ECL respectively). Posterior horns were short and sturdy (35.3\% of ECL), instead the anterior ones were thin and moderately long (50.4\% of ECL). Lateral keels were pronounced (8.7\% of ECW) and presented adhesive fibres (Table 3). To the naked eye, the eggcase surface appeared covered by several fibres; the fresh color varied from reddish brown (PMS 1395, 139) in the eggcase body, to yellowish in the edges (PMS 119) (Fig. 2f; Table 3).

\section{Raja miraletus Linnaeus, $1758(n=34)$}

Active females were caught mostly in late spring and summer (May to August) and only a few times in winter (January), exclusively in the continental shelf (32-158 m depth) (Table 1).

The eggcases were small (Fig. $2 \mathrm{~g}$ ) with a maximum of $56.5 \mathrm{~mm}$ ECL (Table 2) and rectangular in shape (ECW $52.3 \%$ of ECL). The posterior apron was rounded and short (5.5\% of ECL), and the anterior one was straight and three times the length of the anterior (15.2\% of ECL). Posterior horns were short (34.5\% of ECL) and sturdy, while the anteriors were thinner and slightly longer (38.3\% of ECL) (Tables 2, 3). Lateral keels were totally absent and the adhesion fibres were attached to the horns (Table 3). The eggcase surface was covered with visible 
fibres; the fresh color varied from brown (PMS 161) to amber (PMS 138) (Fig. 2g; Table 3).

\section{Raja polystigma Regan, $1923(\boldsymbol{n}=14)$}

As with $R$. asterias and $R$. brachyura, active females were found only during the summer season (June to August) on the continental shelf (38-126 m depth) (Table 1). This skate presented a medium size eggcase (maximum $\mathrm{ECL}=69.2 \mathrm{~mm}$, Table 2) with rectangular shape (ECW $60.9 \%$ of ECL) (Fig. 2h). The eggcases had a rounded and narrow posterior apron and a moderately developed straight anterior one (3.2 and 15.0\% of ECL, respectively) (Table 2). Posterior horns were moderate and sturdy (35.8\% of ECL), instead the anterior ones were thin and had a moderate length (43.9\% of ECL). Lateral keels were narrow (4.4\% of ECW) and had adhesion fibres (Table 3). The fresh color had shades of brown (PMS 133, 161) in the eggcase body, and yellowish in the edges (PMS 126) (Fig. 2h; Table 3).

\section{Statistical analysis}

Eggcase measurements of $D$. nidarosiensis (all found on the sea bed) were excluded from this analysis because they could have been damaged during the recovery in fishing operations (especially the horns) and the measurements could have been different with respect to those found in uteri.

The results of the PCA (Fig. 3) highlighted the existence of the four groups with high dissimilarity values. In particular, group A (composed of eggcases of D. oxyrinchus and $R$. brachyura) was different from groups $\mathrm{B}$ (composed of eggcases of $R$. asterias, $R$. clavata and $R$. polystigma) principally in the eggcase dimension (ECL) and the anterior and posterior aprons length (AAL and PAL) and from group D (L. melitensis) in ECL and PAL. Group C (composed by eggcases of $R$. miraletus) was dissimilar to group B essentially for the lack of the keels (RKW and LKW) and to the other group (A) for eggcase length (ECL), width (ECW) and anterior horn length RAHL and LAHL). Finally, group $\mathrm{D}$ has discriminated from groups $\mathrm{B}$ and $\mathrm{C}$ especially for the anterior horn lengths (RAHL and LAHL) as confirmed also by the SIMPER routine (Table 4 ).

Based on the main eggcase characteristics of each species and their differences with the other ones and considering statistical analysis, we provided a species identification key based on the eggcase descriptions (Table 5).

\section{Eggcase distribution}

Females carrying eggcases of $R$. asterias and $R$. brachyura (Fig. 4) were caught mainly around the west coast in shallow waters (within a depth of $100 \mathrm{~m}$ ) characterized by sandy bottoms in association with the seagrass Posidonia

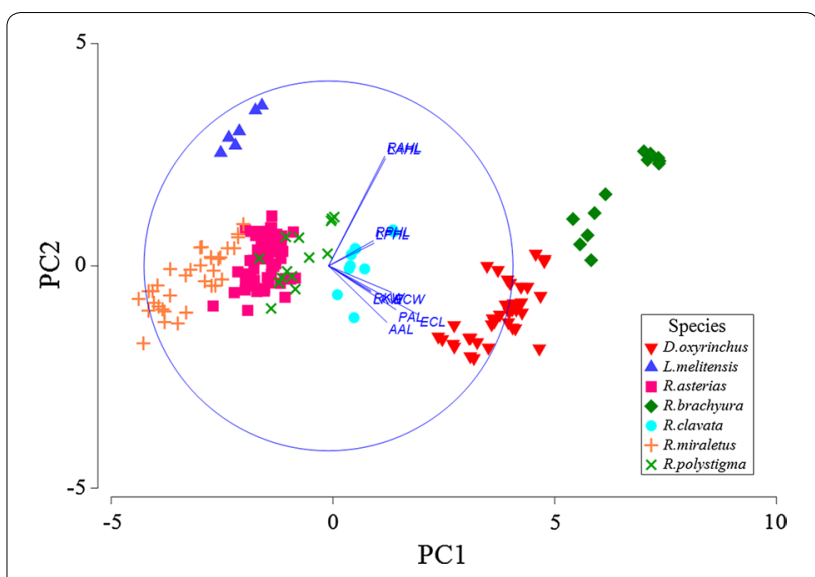

Fig. 3 Principal components analysis (PCA) conducted of eggcase morphometric measurements

oceanica (Linnaeus) Delile 1813, the sea star Astropecten aranciacus (Linnaeus, 1758) and the seaweed Codium bursa Agardh, 1817.

Raja miraletus active females (Fig. 4) were distributed all around Sardinia with the exception of the south-eastern part. The specimens preferred sandy substrata with low algal cover populated mainly by the irregular sea-urchins Spatangus purpureus (Müller, 1776) and the holothuroid Parastichopus regalis (Cuvier, 1817). The highest occurrence of females carrying eggcases was observed in the central western side, with more specimens caught on the same sites $\left(\mathrm{N} 40^{\circ} 11^{\prime} 131^{\prime \prime} \mathrm{E} 8^{\circ} 23^{\prime} 155^{\prime \prime}\right.$ at a depth of $\left.80 \mathrm{~m}\right)$ over several years of sampling. Also $R$. polystigma females were sampled in sandy bottoms within the continental shelf $(38-126 \mathrm{~m})$, but given the few specimens collected (Fig. 4), it was difficult to establish if this species had a geographical preference. The same pattern was observed for $R$. clavata females (Fig. 4), poorly sampled over the years and at a wide depth range ( $42-473 \mathrm{~m})$. D. oxyrinchus females carrying eggcases were observed around all the Sardinian Island (Fig. 4) at a mean depth of $500 \mathrm{~m}$ where the bottoms were mainly muddy and constituted by the bathyal biocoenosis as Axinella cannabina (Esper, 1794), Echinus melo Lamarck, 1816 and Gryphus vitreus (Born, 1778 ). Also the congeneric D. nidarosiensis seemed to prefer muddy substrata; the eggcases and the only one female carrying developing eggcases were found in deep-waters (>750 $\mathrm{m}$ depth) in the south-eastern part of the Island (Fig. 4).

No data about the benthic community associated to $L$. melitensis active were available, but preliminary information on their distribution was given (Fig. 4). 
Table 4 Results of the SIMPER analysis routine considering the morphometric measures in the different groups

\begin{tabular}{|c|c|c|c|}
\hline $\begin{array}{l}\text { Morphometric } \\
\text { measures }\end{array}$ & $\begin{array}{l}\text { Average } \\
\text { squared } \\
\text { distance }\end{array}$ & $\begin{array}{l}\text { Squared } \\
\text { distance/SD }\end{array}$ & Contribution $\%$ \\
\hline Group D versus A & 60.61 & & \\
\hline $\mathrm{ECL}$ & 14.00 & 4.51 & 23.16 \\
\hline PAL & 10.50 & 3.02 & 17.36 \\
\hline ECW & 8.33 & 3.28 & 13.74 \\
\hline Group D versus B & 15.45 & & \\
\hline RAHL & 3.56 & 1.89 & 23.02 \\
\hline LAHL & 3.06 & 1.62 & 19.78 \\
\hline RKW & 2.47 & 2.64 & 15.97 \\
\hline Group A versus B & 38.32 & & \\
\hline $\mathrm{ECL}$ & 10.20 & 2.59 & 26.71 \\
\hline PAL & 6.57 & 2.04 & 17.14 \\
\hline $\mathrm{AAL}$ & 5.12 & 2.55 & 13.37 \\
\hline Group D versus C & 15.26 & & \\
\hline RAHL & 7.21 & 2.28 & 47.26 \\
\hline LAHL & 6.46 & 2.00 & 42.34 \\
\hline Group A versus C & 64.75 & & \\
\hline $\mathrm{ECL}$ & 12.40 & 3.56 & 19.12 \\
\hline ECW & 7.91 & 3.12 & 12.21 \\
\hline $\mathrm{LAHL}$ & 6.81 & 0.94 & 10.52 \\
\hline Group B versus $C$ & 10.88 & & \\
\hline RKW & 2.47 & 2.64 & 22.69 \\
\hline LKW & 2.46 & 2.89 & 22.60 \\
\hline ECW & 1.17 & 0.82 & 10.79 \\
\hline
\end{tabular}

Only highest contributing measures are shown

Group A, D. oxyrinchus and R. brachyura; Group B, R. asterias, R. clavata, $R$. polystigma; Group C, R. miraletus; Group D, L. melitensis; $\mathrm{SD}$, standard deviation

\section{Discussion}

Eggcase reports and information on the egg-laying rate for the overwhelming majority of rajids have received little attention in the Mediterranean context. In this regard, the present study provides updated eggcase descriptions and quantitative data on their sizes for developing regional and specific identification keys, useful in the recognition of eggcases found over sea beds, providing useful information on the distribution and reproductive biology of skates living in the central-western Mediterranean. We do report for the first time information on eggcases of the endemic L. melitensis, considered Critically Endangered in the Mediterranean [36].

The eggcases from the eight analyzed species exhibited peculiar morphologies between genera and even species. Despite some overlap in size between species, features such as horn and apron lengths, and presence/absence of lateral keels were crucial to discriminate the eggcase at species level. In particular, from morphological and morphometric analysis, actually corroborated by multivariate analyses, $R$. miraletus and $L$. melitensis stood out from all the others for having eggcases without keels. Moreover, within the species having keeled eggcases, those belonging to $D$. oxyrinchus and $R$. brachyura were discriminated to the remaining group for having the longest eggcases and aprons (ECL and AAL-PAL).

Considering the ECL (without horns), females of $D$. nidarosiensis possessed, overall, the biggest eggcases (153-177 mm ECL). Our results represent the first available qualitative and quantitative characterization for eggcases from this species in the Mediterranean basin.

\section{Table 5 Identification key for rajid eggcases of central-western Mediterranean}

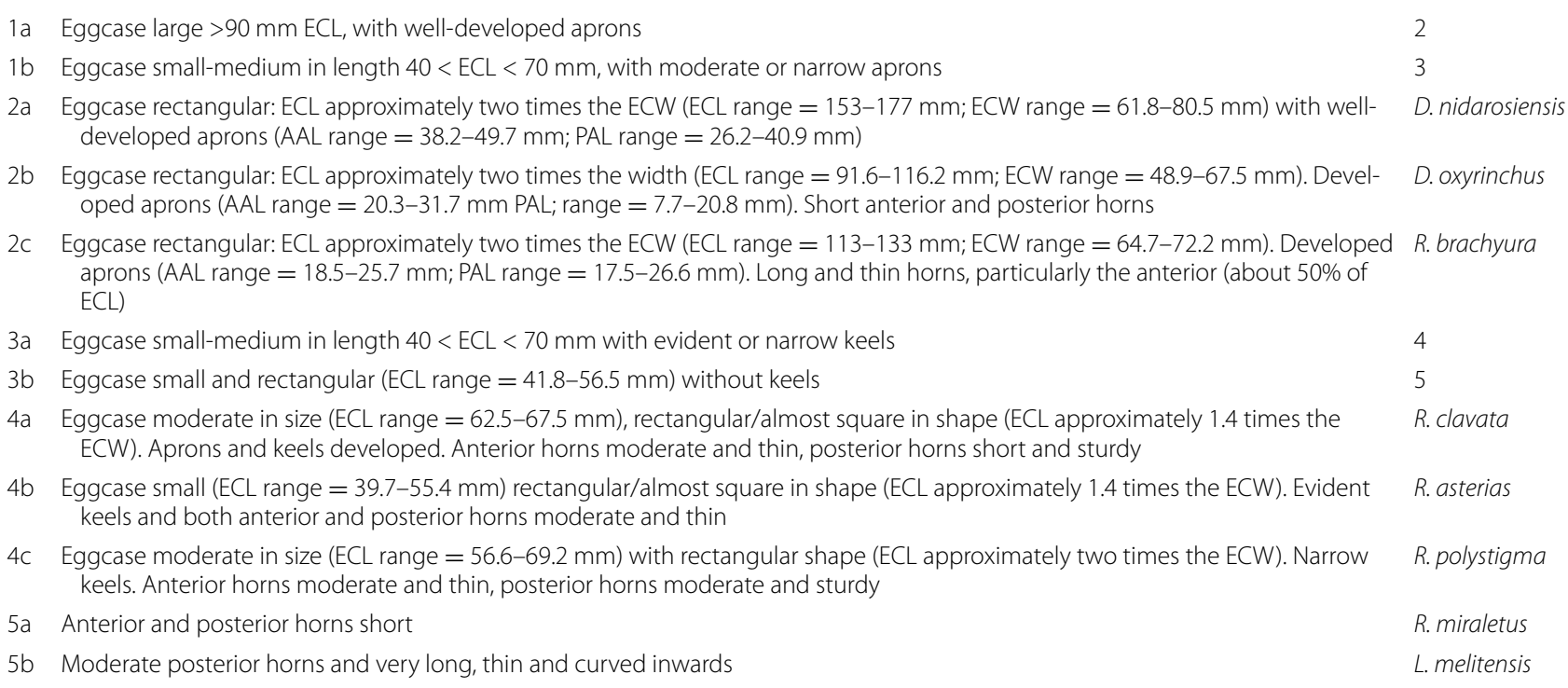




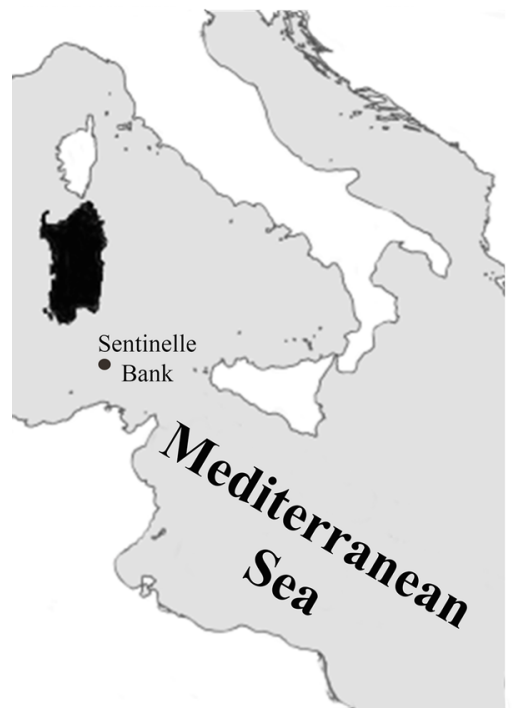

Leucoraja melitensis

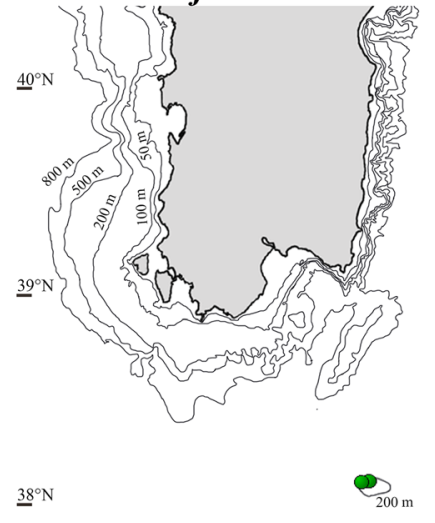

$18^{\circ} \mathrm{E}$

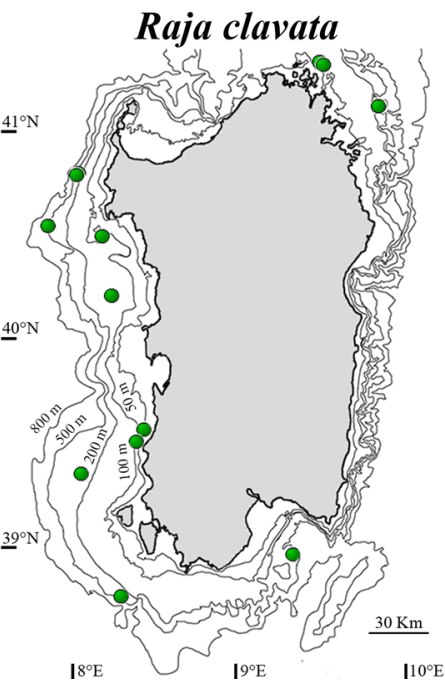

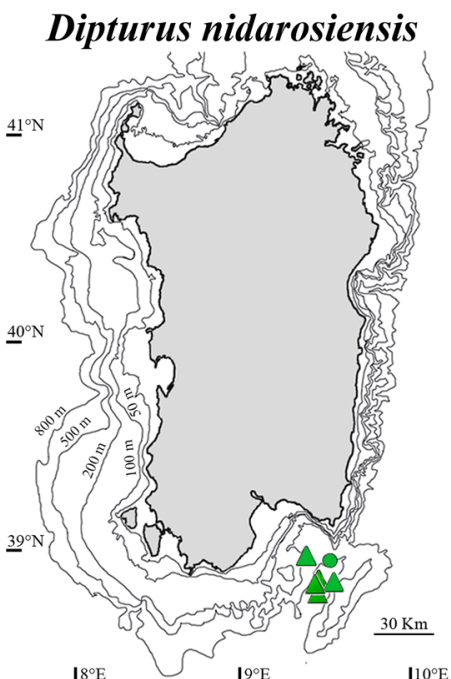

Raja asterias

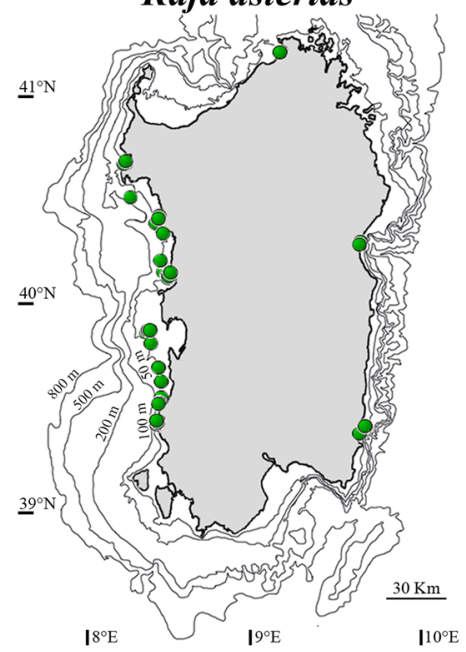

$110^{\circ} \mathrm{E}$

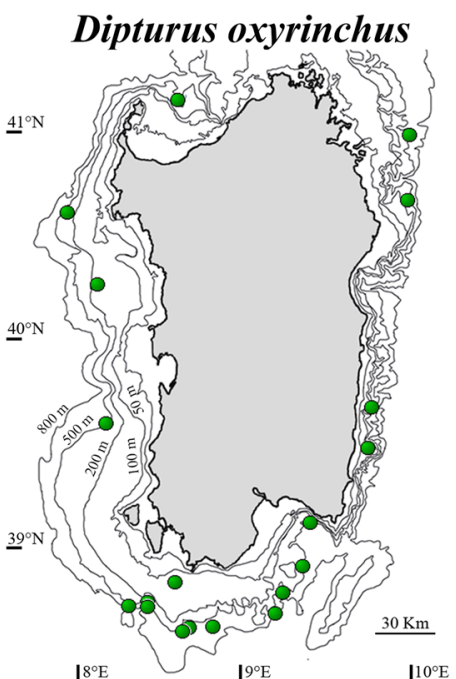

Raja brachyura

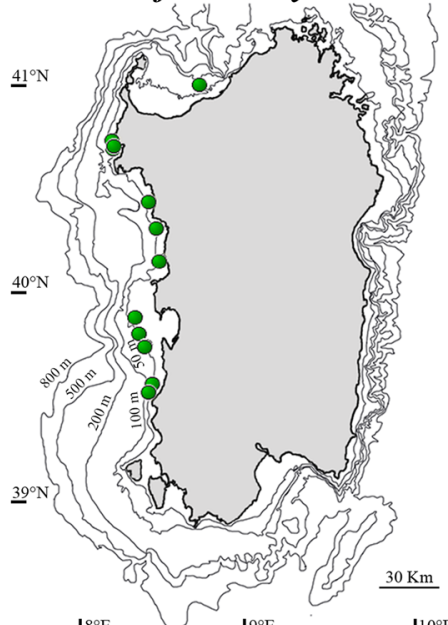

$18^{\circ} \mathrm{E} \quad 19^{\circ} \mathrm{E} \quad 10^{\circ} \mathrm{E}$
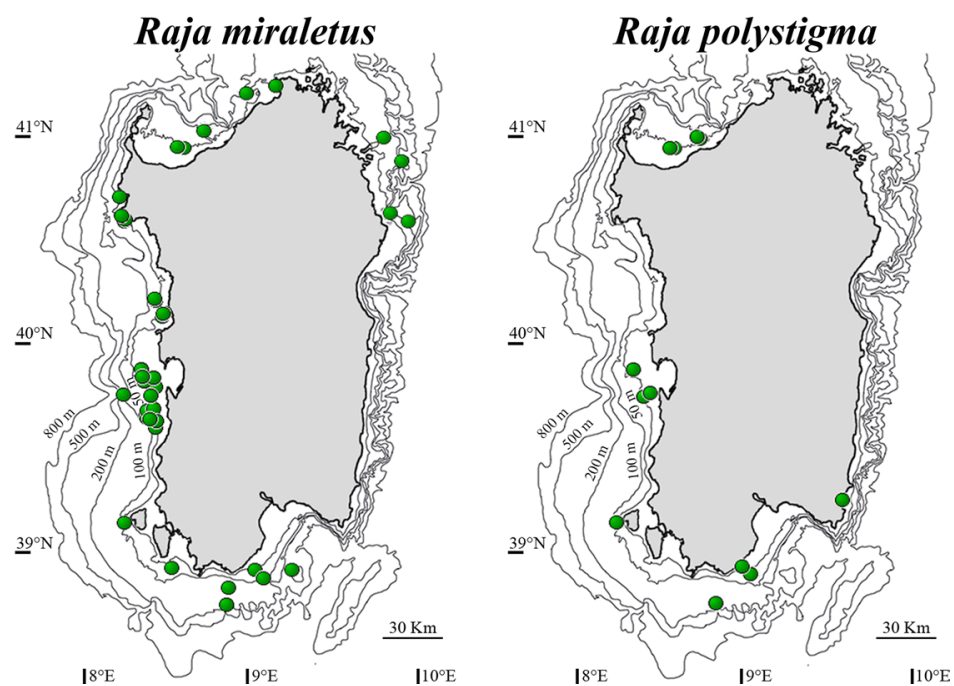

Fig. 4 Map of the study area where active females (filled circle) of the eight investigated species and eggcases (filled triangle) laid on the bottom were indicated 
In addition, considering the two distinct eggcase forms described in literature for the genus Dipturus [17], on the basis of our observations, it was possible to insert $D$. nidarosiensis and D. oxyrinchus in the D-II phylogenetic type. The latter, matching with other Dipturus species (e.g. D. gigas [13], D. trachiderma [16], D. batis [17]) was characterized by well-developed aprons and lateral keel united with the main portion rectangular in shape, differently from the D-I type showing close resemblance from other genera of the family Rajidae [17].

Generally, the length of the horns shows rather large intraspecific variations with the anterior horns longer than the posteriors [12, 37, 38]. In our specific case, eggcases of $L$. melitensis presented the longest anterior horns (intertwining) with a ratio anterior/posterior horns of 2.6, followed by R. brachyura egg cases with a ratio of 1.6 , that enable them to be fixed to various structures as seagrasses, algae or debris. In other studies, similar, or even higher horn proportions were found in other species belonging to the family Rajidae as Atlantoraja cyclophora and A. platana [18], Leucoraja naevus [38], Rioraja agassizi [39] and Psammobatis scobina [37].

Almost all the analyzed eggcases were covered by adhesive fibers providing their camouflage and anchoring to marine debris, plants, mud and rock and may function as a barrier to predation [40]. As a general rule, eggcases covered by fibers were produced by mixed gland tubules (mucous and serous) situated deep in the terminal zone of the oviducal gland as reported for many Rajidae species (e.g. $D$. oxyrinchus, $R$. montagui, $R$. brachyura, $R$. clavata and $R$. undulata) by Maia et al. [38] and Marongiu et al. [41]. $L$. melitensis differed from the remaining species, because its eggcases were smooth, devoid of fibres on their surface. This feature seems to be common to other species belonging to the genus Leucoraja, as L. naevus, marked by the mucous gland tubules secretions (suphated acid mucins) of the terminal zone that could work as an important chemical defense against predation and pathogens $[42,43]$.

Furthermore, D. nidarosiensis, D. oxyrinchus and $R$. brachyura eggcases were the most robust. This feature was certainly related to their oviducal gland microarchitecture, characterized by a higher number of lamellae of the baffle zone [38, 41], if compared with the eggcases from $R$. miraletus characterized by a lower number of lamellae [41]. From an ecological perspective, these features, probably due to the length of the developmental period, may represent an advantage against predation and water turbulence [38] considering that their big dimensions did not allow a proper camouflage.

Sandy bottoms $(<100-150 \mathrm{~m}$ depth) were identified as egg-laying sites (i.e. sites with females bearing eggcases in uteri) of many species belonging to genus Raja (e.g. R. asterias, $R$. brachyura, $R$. miraletus and $R$. polystigma). A similar behavior was observed for $R$. brachyura females in Portugal [38] and around the British Isles [44] as well as for R. miraletus in the south west of India where eggcases were found on the soft sea bed at a depth range of 112-123 $\mathrm{m}$ [45].

With the exception of $R$. polystigma, all other species showed a clear distribution in the western part of Sardinia, which is characterized by a wide continental shelf (tens of kilometres) and a continental margin dwelling between a depth of 150 and $200 \mathrm{~m}$ depth, contrarily to other sides (especially the eastern side), where the shelf is narrower and steeper [46]. Regarding $R$. clavata, it presented a high diversity of egg-laying habitats with a wide bathymetric range, which may differ in terms of bottom topography or sediment composition, as reported also by other authors in the Atlantic Ocean $[38,44]$. Finally, D. oxyrinchus active females showed a clear preference for deep muddy bottoms (mean depth of $500 \mathrm{~m}$ ) around Sardinia, confirming their bathyal habits as reported for the same waters by Mulas et al. [47]. The occurrence of $D$. nidarosiensis, exclusively in the south eastern part, was related to the deep trawl-surveys performed only in that area.

Throughout the analyzed period (12 years), $R$. asterias and $R$. miraletus active skates were found on the same sites every year, located in the central western coast of Sardinia, confirming the theory that many rajid species demonstrate site fidelity, returning to the same depositional area or nursery ground on an annual basis as reported for Bathyraja aleutica, B. interrupta and B. parmifera in eastern Bearing Sea [48]. Moreover, this finding could also suggest the existence of possible nursery areas, as recently observed for oviparous species as $R$. clavata and Galeus melastomus [49] and Scyliorhinus canicula [50] around Sardinian waters.

Because of their inherent low fecundity and slow growth rates, skates may reproduce with distinct seasonal pulses, over protracted periods, or in some cases continuously throughout the year $[51,52]$. In this regard, our results suggested a continuous reproduction throughout the year for the deeper $D$. oxyrinchus confirmed by the presence of spawning capable females during all seasons with a predominance of active individuals in autumn and winter months (late September to late March) [53]. A reproduction restricted mainly to summertime was described, instead, for the other species (except for $L$. melitensis for which no sufficient reproductive data was available), as also confirmed by other studies in Italian waters $[54,55]$. Year-round reproduction may be a strategy to compensate the high maternal energy investment and late maturity typical to the elasmobranchs. Given the generalized high biological productivity in the summer period, a distinct pulse of egg deposition during this period could represent an advantage for those species with shallower habits in order to maximize the fitness. 
Table 6 Eggcase dimensions reported in several geographical areas by latitudinal clines

\begin{tabular}{|c|c|c|c|c|}
\hline Species & Eggcase length (mm) & Eggcase width (mm) & Area & References \\
\hline \multirow[t]{3}{*}{ D. nidarosiensis } & $182-260$ & $95-120$ & Atlantic (Norwegian Sea) & [56] \\
\hline & $182-260$ & $92-113$ & Atlantic (North Sea) & {$[57]$} \\
\hline & $153-177(170.2 \pm 9.8)$ & $61.8-80.5(74.8 \pm 7.5)$ & Mediterranean (Sardinia) & Present study \\
\hline \multirow[t]{8}{*}{ D. oxyrinchus } & 133 & 79.5 & Atlantic (British waters) & {$[58]$} \\
\hline & $128-133$ & 74-101 & Atlantic (British waters) & [59] \\
\hline & $120-235$ & $58-120$ & Atlantic (North Sea) & Bor [57] \\
\hline & $102-126(112 \pm 10.4)$ & $60-66(63.8 \pm 2.6)$ & Atlantic (British waters) & [30] \\
\hline & $100-150$ & - & Mediterranean/Atlantic & [3] \\
\hline & $91.6-116.2(103.8 \pm 5.3)$ & $48.9-67.5(57 \pm 4.0)$ & Mediterranean (Sardinia) & Present study \\
\hline & $35-46(38.4 \pm 0.7)$ & $17-28(24.2 \pm 0.2)$ & Mediterranean (Tunisia) & {$[23]$} \\
\hline & 140 & - & Mediterranean (Naples) & {$[21]$} \\
\hline L. melitensis & $42.3-45(44.1 \pm 1.0)$ & $22.4-26.0(23.9 \pm 1.4)$ & Mediterranean (Sentinelle Bank) & Present study \\
\hline \multirow[t]{3}{*}{ R. asterias } & $30-45$ & - & Mediterranean & {$[3]$} \\
\hline & $39.7-55.4(48.3 \pm 3.0)$ & $22.4-40.5(33.7 \pm 2.6)$ & Mediterranean (Sardinia) & Present study \\
\hline & 45 & - & Mediterranean (Naples) & {$[21]$} \\
\hline \multirow[t]{11}{*}{ R. brachyura } & $122 \pm 5$ & $68 \pm 4$ & Atlantic (Portuguese waters) & [38] \\
\hline & 136 & 76 & Atlantic (British waters) & [60] \\
\hline & 128.4 & 78.5 & Atlantic (British waters) & [58] \\
\hline & $115-143$ & $72-90$ & Atlantic (British waters) & [59] \\
\hline & $82-132.2(108.6 \pm 10.1)$ & $32.7-86.4(65.4 \pm 11.7)$ & Atlantic (British waters) & [30] \\
\hline & 121 & 79 & Atlantic (North Sea) & [61] \\
\hline & 115 & 70 & Atlantic (North Sea) & [62] \\
\hline & 120 & - & Mediterranean/Atlantic & [3] \\
\hline & $115-143$ & - & Mediterranean & {$[15]$} \\
\hline & $113-133(119.3 \pm 4.9)$ & $64.7-72.2(69.5 \pm 2.3)$ & Mediterranean (Sardinia) & Present study \\
\hline & 105 & - & Mediterranean (Naples) & {$[21]$} \\
\hline \multirow[t]{11}{*}{ R. clavata } & $65 \pm 5$ & $48 \pm 5$ & Atlantic (Portuguese waters) & {$[38]$} \\
\hline & 80 & 50 & Atlantic (France) & {$[63]$} \\
\hline & $63-90(74.9)$ & $49-68.5(67.1)$ & Atlantic (British waters) & {$[58]$} \\
\hline & $60-90$ & $50-70$ & Atlantic (British waters) & [59] \\
\hline & $32.7-83.3(67.2 \pm 10)$ & $32.7-69(37 \pm 8.2)$ & Atlantic (British waters) & {$[30]$} \\
\hline & 70 & 50 & Atlantic (North Sea) & {$[62]$} \\
\hline & $60-90$ & - & Mediterranean/Atlantic & [3] \\
\hline & $61-66$ & - & Mediterranean (France) & {$[22]$} \\
\hline & $62.5-67.5(64.1 \pm 1.9)$ & $41.7-47.4(43.8 \pm 2.0)$ & Mediterranean (Sardinia) & Present study \\
\hline & $70-78(75)$ & $50-54(52)$ & Mediterranean (Tunisia) & [64] \\
\hline & 60 & - & Mediterranean (Naples) & {$[21]$} \\
\hline \multirow[t]{7}{*}{ R. miraletus } & $48-52$ & - & Atlantic (Senegal) & {$[65]$} \\
\hline & $46 \pm 3$ & $26 \pm 2$ & Atlantic (Portuguese waters) & {$[38]$} \\
\hline & $<50$ & - & Atlantic (South Africa) & {$[66]$} \\
\hline & $45-52$ & - & Mediterranean/Atlantic & {$[3]$} \\
\hline & $41.8-56.5(47.4 \pm 4.0)$ & $22.8-29.2(24.7 \pm 1.7)$ & Mediterranean (Sardinia) & Present study \\
\hline & $42-47$ & - & Mediterranean (Tunisia) & {$[67]$} \\
\hline & 59 & - & Indian Ocean & {$[45]$} \\
\hline \multirow[t]{2}{*}{ R.polystigma } & $35-46$ & - & Mediterranean & [3] \\
\hline & $56.6-69.2(62.3 \pm 4.3)$ & $33.9-44.3(37.9 \pm 2.9)$ & Mediterranean (Sardinia) & Present study \\
\hline
\end{tabular}


We also observed that eggcase dimensions seem to change in relation to geographical area. From a comparison with the available literature from the Mediterranean (Table 6), our samples were similar in sizes (ECL and ECW) to those observed in other areas of the basin. Instead, eggcases analysed here (excluding the endemic species) seemed to be smaller than those described in the Atlantic studies (Table 6). The only exception was represented by $R$. brachyura, showing eggcases slightly larger than the Atlantic ones, probably due to similar body dimensions between the two areas [55]. This pattern was reported also for other chondrichthyan eggcases (e.g. G. melastomus, [28]) and it could probably be due to the intraspecific latitudinal cline in elasmobranchs size in which Atlantic specimens reach a bigger body size than Mediterranean ones [26, 39, 68].

In conclusion, given the absence of Mediterranean eggcase descriptions, the present study should shed light on the taxonomy, distribution and reproductive habits of many Mediterranean skates. Indeed, this identification key could act as useful tool for non-invasive identification of eggcases through image analysis (i.e., ROV imaging), which have proven to be an efficient tool for identifying nursery ground and delineate ecological traits of species. In addition, since knowledge of the location of nursery grounds for elasmobranchs is practically nonexistent [50] and given the most recent policy approaches to the protection of marine ecosystems (e.g. the Marine Strategy Framework Directive, MSFD; 2008/56/EC currently in force in European seas), the identification of essential fishing habitats such as nursery grounds of sensitive species like skates represent an indispensable component to protect and manage.

\section{Abbreviations \\ n: number of eggcase analyzed; TL: total length; ECL: eggcase length; ECW: eggcase width; AAL: anterior apron length; PAL: posterior apron length; LKW: left keel width; RKW: right keel width; LAHL: left anterior horn length; RAHL: right anterior horn length; LPHL: left posterior horn length; RPHL: right posterior horn length; PCA: Principal Component Analysis; SIMPER procedure: SIMilarity PERcentage Analysis; ANOSIM: Similarity Randomization Test. \\ Authors' contributions \\ $C P, M F M$ and MCF conceived the study; CP wrote the manuscript with signifi- cant input of MFM and MCF. MFM and CP analyzed, described and measured all specimens' samples and wrote the morphometric and morphological part of the manuscript. AC performed statistical analysis; RM performed molecular analysis to genetic identification; CP, MFM, MCF, AB, AM, RC, LV and GS performed sampling and all the analyses and data handling. All authors contributed to data interpretation. All authors read and approved the final manuscript.}

\section{Author details \\ ${ }^{1}$ Department of Life and Environmental Sciences (DISVA), University of Cagli- ari, Via Fiorelli 1, 09126 Cagliari, Italy. ${ }^{2}$ Department of Architecture, Design and Urban Development, University of Sassari, Palazzo Pou Salit, Piazza Duomo} 6, 07041 Alghero, Italy.

\section{Competing interests}

The authors declare that they have no competing interests.

\section{Availability of data and materials}

The datasets used and/or analyzed during the current study available from the corresponding author on reasonable request.

\section{Ethics approval and consent to participate}

All applicable international, national and/or institutional guidelines for the care and use of animals were followed.

\section{Funding}

This study was financed by Autonomous Region of Sardinia within the frame of the research project'Approccio multidisciplinare per la conservazione e gestione della selacofauna del Mediterraneo' (LR7 CRP-25321) and carried out within the Data Collection Regulation and Framework-module trawl surveys MEDITS (Mediterranean International Trawl Surveys).

\section{Publisher's Note}

Springer Nature remains neutral with regard to jurisdictional claims in published maps and institutional affiliations.

Received: 8 November 2016 Accepted: 15 June 2017

Published online: 24 June 2017

\section{References}

1. Ebert D, Compagno LJV. Biodiversity and systematics of skates (Chondrichthyes: Rajiformes: Rajoidei). Environ Biol Fish. 2007;80:111-24

2. Carrier JC, Musick JA, Heithaus MR. Biology of sharks and their relatives. Boca Raton: CRC Press; 2004.

3. Stehmann M, Burkel DL. Rajidae. In: Whitehead PJP, Bauchot ML, Hureau JC, Nielsen J, Tortonese E, editors. Fishes of the north-eastern Atlantic and Mediterranean, vol. 1. Paris: UNESCO; 1984. p. 163-96.

4. Hunter E, Berry F, Buckley AA, Stewart C, Metcalfe JD. Seasonal migration of thornback rays and implications for closure management. J Appl Ecol. 2006:43:710-20.

5. Hitz CR. Observations on egg cases of the big skate (Raja binoculata Girard) found in Oregon coastal waters. J Fish Res Can. 1964;21:851-4.

6. Conrath $\mathrm{CL}$, Musick JA. Reproductive biology of elasmobranchs. In: Carrier JC, Musick JA, Heithaus MR, editors. Biology of sharks and their relatives. 2nd ed. Boca Raton, FL: CRC Press; 2012. p. 291-312.

7. Berestovskii EG. Reproductive biology of skates of the family Rajidae in the seas of the Far North. J Ichthyol. 1994;34(6):26-37.

8. Hoff GR. Reproduction of the Alaska skate (Bathyraja parmifera) with regard to nursery sites, embryo development and predation. Seattle: University of Washington; 2007.

9. Musick JA, Ellis JK. Reproductive evolution of chondrichthyans. In: Hamlett WC, editor. Reproductive biology and phylogeny of chondrichthyes: sharks, rays and chimaeras. Endfield: Science Publishers; 2005. p. 45-79.

10. Ebert DA, Davis CD. Description of skate egg cases (Chondrichthyes: Rajiformes: Rajoidei) from the eastern North Pacific. Zootaxa. 2007:1393:1-18.

11. Ebert DA, Smith WD, Cailliet GM. Reproductive biology of two commercially exploited skates, Raja binoculata and R. rhina, in the western Gulf of Alaska. Fish Res. 2008:94:48-57.

12. Ishiyama R. Observations on the egg-capsules of the skates of the Family Rajidae, found in Japan and its adjacent waters. Bull Mus Comp Zool. 1958;118(1):1-24

13. Ishiyama R. Studies on the Rajid fishes (Rajidae) found in the waters around Japan. J Shimoneseki Univ Fish. 1958;7(2, 3):193-394.

14. Ishiyama R, Hubbs CL. Bathyraja, a genus of Pacific skates (Rajidae) regarded as phyletically distinct from the Atlantic genus Breviraja. Copeia. 1968:2:407-10.

15. Tortonese E. Leptocardia, ciclostomata, selachii. Fauna d'Italia, vol. 2. Bologna: Edizioni Calderini; 1956.

16. Mabragaña E, Figueroa DE, Scenna LB, Díaz de Astarloa JM, Colonello JH, Delpiani G. Chondrichthyan egg cases from the southwest Atlantic. J Fish Biol. 2011;79:1261-90.

17. Ishihara H, Treloar M, Bor P, Senou H, Jeong C. The comparative morphology of skate egg capsules (Chondrichthyes: Elasmobranchii: Rajiformes). Bull Kanagawa Prefect Mus (Nat Sci). 2012;41:9-25. 
18. Oddone MC, Marçal AS, Vooren CM. Egg capsules of Atlantoraja cyclophora (Regan, 1903) and A. plantana (Günterm, 1880) (Pisces, Elasmobranchii, Rajidae). Zootaxa. 2004;426:1-4.

19. Serena F, Mancusi C, Barone M. Guida pratica di identificazione delle razze (Rajidae) del Mar Mediterraneo. Linee guida per la raccolta e l'analisi dei dati. Biol Mar Mediterr. 2010;17(2):204.

20. Dulvy NK, Fowler SL, Musick JA, Cavanagh RD, Kyne PM, Harrison LR, et al. Extinction risk and conservation of the world's sharks and rays. eLife. 2014;3:e00590.

21. Lo Bianco S. Notizie biologiche riguardanti specialmente il periodo di maturità sessuale degli animali del golfo di Napoli. Mitt Zool Stn Neapel. 1909:19(4):513-761.

22. Capapé C, Guélorget O, Siau Y, Vergne Y, Quignard JP. Reproductive biology of the thornback ray Raja clavata L., 1758, (Chondrichthyes: Rajidae) from the coast of Languedoc (Southern France, Northern Mediterranean) Vie Milieu. 2007;57(1-2):83-90.

23. Kadri H, Marouani S, Bradai MN, Bouaïn A, Morize E. Age, growth, longevity, mortality and reproductive biology of Dipturus oxyrinchus, (Chondrichthyes: Rajidae) off the Gulf of Gabès (Southern Tunisia, central Mediterranean). J Mar Biol Assoc. 2014;95(3):569-77.

24. Cannas R, Follesa MC, Cabiddu S, Porcu C, Salvadori S, Iglésias SP, Deiana AM, Cau A. Molecular and morphological evidence of the occurrence of the Norwegian skate Dipturus nidarosiensis (Storm, 1881) in the Mediterranean Sea. Mar Biol Res. 2010;6(4):341-50.

25. Follesa MC, Cannas R, Cabiddu S, Cau A, Mulas A, Porcu C, Cau A. Preliminary observations of the reproductive biology and diet for the Norwegian skate Dipturus nidarosiensis (Rajidae) from the Central Western Mediterranean Sea. Cybium. 2012;36(3):473-7.

26. Finotto L, Gristina M, Garofalo G, Riginella E, Mazzoldi C. Contrasting life history and reproductive traits in two populations of Scyliorhinus canicula. Mar Biol. 2015;162(6):1175-86

27. Capapé C, Zaouali J. Biology of Scyliorhinidae from Tunisian coasts. Vl: Galeus melastomus Rafinesque, 1810: bathymetric and geographical distribution, sexuality, reproduction, fecundity. Cah Biol Mar. 1977;18(4):449-63.

28. Cabiddu S, Atzori G, Mereu M, Palmas F. Egg-cases of Galeus melastomus (Chondrichthyes, Scyliorhinidae) in Sardinian waters. In: Rapport du 40e Congrés de la CIESM, 40th Ciesm Congress Proceedings, Marseille (France). 2013. p. 500

29. Ivanova NV, Zemlak TS, Hanner RH, Hebert PDN. Universal primer cocktails for fish DNA barcoding. Mol Ecol Notes. 2007;7:544-8.

30. Gordon CA, Hood AR, Ellis JR. Descriptions and revised key to the eggcases of the skates (Rajiformes: Rajidae) and catsharks (Carcharhiniformes: Scyliorhinidae) of the British Isles. Zootaxa. 2016;4150(3):255-80.

31. Concha F, Oddone MC, Bustamante C, Morales N. Egg capsules of the yellownose skate Zearaja chilensis (Guichenot 1848) and the roughskin skate Dipturus trachyderma (Krefft and Stehmann 1974) (Rajiformes: Rajidae) from the south-eastern Pacific Ocean. Ichthyol Res. 2012;59:323-7.

32. Clarke KR, Gorley RN. PRIMER v6: user manual/tutorial. Plymouth: PRIMERE; 2006

33. Clarke KR. Non parametric multivariate analyses of changes in community structure. Aust J Ecol. 1993;18:117-43.

34. Riedl R. Fauna e flora del Mediterraneo. Dalle alghe ai mammiferi: una guida sistematica alle specie che vivono nel mar Mediterraneo. Padova: Franco Muzzio Editore; 2005

35. Cariani A, Messinetti S, Ferrari A, Arculeo M, Bonello JJ, Bonnici L, Cannas R, Carbonara P, Cau A, Charilaou C, El Ouamari N, Fiorentino F, Follesa MC, Garofalo G, Golani D, Guarniero I, Hanner R, Hemida F, Kada O, Lo Brutto S, Mancusi C, Morey G, Schembr PJ, Serena F, Sion L, Stagioni M, Tursi A, Vrgoc N, Steinke D, Tinti F. Improving the conservation of Mediterranean chondrichthyans: the ELASMOMED DNA barcode reference library. PLOS ONE. 2017:12(1):e0170244. doi:10.1371/journal.pone.0170244.

36. Dulvy NK, Allen DJ, Ralph GM, Walls RHL. The conservation status of sharks, rays and chimaeras in the Mediterranean Sea (Brochure). Malaga: IUCN; 2016.

37. Concha F, Hernàndez S, Oddone MC. Egg capsules of the raspthorn sandskate, Psammobatis scobina (Philippi, 1857) (Rajiformes, Rajidae). Rev Biol Mar Oceanogr. 2009:44:253-6.

38. Maia C, Serra-Pereira B, Erzini K, Figueiredo I. How is the morphology of the oviducal gland and of the resulting egg capsule associated with the egg laying habitats of Rajidae species? Environ Biol Fishes. 2015;98:2037-48

39. Oddone MC, Mesa A, Amorim A. The egg capsule of Rioraja agassizi (Müller \& Henle) (Elasmobranchii, Rajidae), endemic to the SW Atlantic. Panam J Aquat Sci. 2006:1:43-8.

40. Hoff GR. Skate Bathyraja spp. egg predation in the eastern Bering Sea. J Fish Biol. 2009:74:250-69.

41. Marongiu MF, Porcu C, Bellodi A, Cuccu D, Mulas A, Follesa MC. Oviducal gland microstructure of Raja miraletus and Dipturus oxyrinchus (Elasmobranchii, Rajidae). J Morphol. 2015;276:1392-403.

42. Bansil R, Turner BS. Mucin structure, aggregation, physiological functions and biomedical applications. Curr Opin Colloid Interface Sci. 2006;11:164-70.

43. Menkhorst E, Selwood L. Vertebrate extracellular preovulatory and postovulatory egg coats. Biol Reprod. 2008;79:790-7.

44. Ellis JR, Cruz-Martínez A, Rackham BD, Rogers SI. The distribution of chondrichthyan fishes around the British Isles and implications for conservation. J Northw Atl Fish Sci. 2005:35:195-213.

45. Chembian AJ. Description of spawning ground and egg capsules of the batoid Raja miraletus Linnaeus, 1758 in the Wadge Bank, along the southwest coast of India. Indian J Fish. 2010;57(1):13-6.

46. Palomba M, Ulzega A. Geomorfologia dei depositi quaternari del Rio Quirra e della piattaforma continentale antistante (Sardegna Orientale). Cagliari: Rendiconti del Seminario della Facoltà di Scienze; 1984.

47. Mulas A, Bellodi A, Cannas R, Cau A, Cuccu D, Marongiu MF, Porcu C, Follesa MC. Diet and feeding behaviour of longnosed skate Dipturus oxyrinchus. J Fish Biol. 2015;86(1):121-38.

48. Hoff GR. Identification of skate nursery habitat in the eastern Bering Sea. Mar Ecol Prog Ser. 2010;403:243-54

49. Colloca F, Garofalo G, Bitetto I, Facchini MT, Grati F, Martiradonna A, et al. The seascape of demersal fish nursery areas in the North Mediterranean Sea, a first step towards the implementation of spatial planning for trawl fisheries. PLOS ONE. 2015:10(3):e0119590.

50. Cau A, Follesa MC, Moccia D, Bellodi A, Mulas A, Bo M, Canese S, Angiolillo M, Cannas R. Leiopathes glaberrima millennial forest from SW Sardinia as nursery ground for the small spotted catshark Scyliorhinus canicula. Aquatic Conserv Mar Freshw Ecosyst. 2016. doi:10.1002/aqc.2717.

51. Sulikowski JA, Kneebone J, Elzey S, Jurek J, Danley PD, Howell WH, Tsang PCW. The reproduction cycle of the thorny skate (Amblyraja radiata) in the western Gulf of Maine. Fish Bull. 2005;103:536-43.

52. Templeman W. Development, occurrence and characteristics of egg capsules of the thorny skate, Raja radiata, in the northwest Atlantic. J Northw Atl Fish Sci. 1982;3:47-56.

53. Bellodi A, Porcu C, Cannas R, Cau A, Marongiu MF, Mulas A, Vittori S, Follesa MC. Life-history traits of the long-nosed skate Dipturus oxyrinchus, from the central-western Mediterranean Sea. J Fish Biol. 2017;90:867-88.

54. Barone M, De Ranieri S, Fabiani O, Pirone A, Serena F. Gametogenesis and maturity stages scale of Raja asterias Delaroche, 1809 (Chondrichthyes, Raijdae) from the South Ligurian Sea. Hydrobiologia. 2007;580(1):245-54.

55. Porcu C, Bellodi A, Cannas R, Marongiu MF, Mulas A, Follesa MC. Lifehistory traits of a commercial ray, Raja brachyura from the central western Mediterranean Sea. Mediterr Mar Sci. 2015;16(1):90-102.

56. Nordgaard O. Contributions to the life history of the fishes in Trondhjem Fjord and environs. Meddelelse fra Trondhjems Biologiske Station 1917:10:38.

57. Bor P. Egg-capsules of sharks and skates. 2006. http://home.planet. $\mathrm{nl} /$ por00213/enter.html. Accessed 5 June 2016.

58. Clark R. Rays and skates (Raiae). J Mar Biol Assoc. 1922;12:577-641.

59. Wheeler A. The fishes of the British Isles and north-west Europe. East Lansing: Michigan State University Press; 1969.

60. Williamson HC. On the eggs of certain skates (Raja). Natl Museum Can Bull. 1913:1:3-6.

61. Lacourt AW. Eikapsels van de kraakbeenvissen, roggen, haaien, draakvissen (Chondrichtyes) van Noord en West Europa. Utrecht: Wetenschappelijke Mededeling Koninklijke Nederlandse Natuurhistorische Vereniging; 1979.

62. Bor PHF. Eikapsels van haaien en roggen. Wetenschappelijke Mededeling Koninklijke Nederlandse Natuuristhorische Vereninging 1998;223:1-48.

63. Le Danois E. Contribution a l'étude systématique et biologique des poissons de la Manche occidentale. Thèses, Faculté des Sciences de Paris; 1913 
64. Capapé C. Contribution à la biologie des Rajidæ des côtes tunisiennes. III. Raja clavata Linné, 1758. Répartition géographique et bathymétrique, sexualité, reproduction et fécondité. Bull. Mus. Nat. Hist. Paris, 3ème Série, n 393. Zoology. 1976;275:907-22.

65. Capapé C, Diatta Y, Seck AA, Guélorget O. Aspects of the reproductive biology of the brown ray Raja miraletus (Chondrichthyes: Rajidae) from the coast of Senegal (Eastern Tropical Atlantic). Cah Biol Mar. 2007;48:169-78

66. Ebert DA, Compagno LJV, Cowley PD. Aspects of the reproductive biology of skates (Chondrichthyes: Rajiformes: Rajoidei) from southern Africa. ICES J Mar Sci. 2008;65:81-102.
67. Capapé C, Quignard JP. Essai d'évaluation de la fécondité chez les Sélaciens ovipares: cas de Raja miraletus Linné, 1758 et de $R$. radula Delaroche, 1809 des côtes tunisiennes. Arch Inst Pasteur Tunis. 1975;52(3):263-76.

68. Costa ME, Erzini K, Borges TC. Reproductive biology of the blackmouth catshark, Galeus melastomus (Chondrichthyes: Scyliorhinidae) off the south coast of Portugal. J Mar Biol Assoc UK. 2005;85:1173-83.

\section{Submit your next manuscript to BioMed Central and we will help you at every step:}

- We accept pre-submission inquiries

- Our selector tool helps you to find the most relevant journal

- We provide round the clock customer support

- Convenient online submission

- Thorough peer review

- Inclusion in PubMed and all major indexing services

- Maximum visibility for your research

Submit your manuscript at

www.biomedcentral com/submit 